\title{
Environmental Education - A Model of the Gulf Stream
}

\author{
Renata Holubova* \\ Department of Experimental Physics, Faculty of Science, Palacky University, Olomouc, Czech Republic \\ *Corresponding author: renata.holubova@upol.cz
}

Received July 09, 2015; Revised July 27, 2015; Accepted August 10, 2015

\begin{abstract}
Environmental education is a part of the Framework Educational Programme for Basic Education in the Czech Republic and is supported all over the world. The goal of our activity was the use of models in environmental education. Our attention was focused on the knowledge about one of the environmental problems due to global warming - the properties of the Gulf Stream, and its improvement. The Gulf Stream is one of the most famous sea currents and, in connection with the problems of global warming, also much discussed. The aim of the project was to prepare a simple flow model of the Gulf Stream. In the first part of the paper the impact of environmental education is mentioned. In the second part the model of the Gulf Stream is described. The model is the starting point for the discussion and further reading about the ocean and atmosphere transport of heat. The key points of the discussed problems are the impact of the Gulf Stream, and the slowing down of the Gulf Stream. It is thought that gen Y are the best educated generation in environmental problems. But most information Millennials get from TV, Internet, newspapers, and sometimes the information are questionable and insufficient. This model will help the learners get deeper knowledge of heat transport.
\end{abstract}

Keywords: environmental education, model, gulf stream, experiment

Cite This Article: Renata Holubova, "Environmental Education - A Model of the Gulf Stream.” American Journal of Educational Research, vol. 3, no. 8 (2015): 1057-1061. doi: 10.12691/education-3-8-18.

\section{Introduction}

To motivate the generation Y (Millennials) learners to study science is very difficult. Many papers which discussed the problem how to motivate Millennials to study science were published earlier $[2,4,16]$. At the Department of Experimental Physics in Olomouc a lot of stimulating activities and interdisciplinary modules were prepared $[7,8]$. The aim of our latest project was to make use of environmental problems for motivation of the new generation to study science. This project will be described in this paper.

Millenials typically wants strongly belief that things they are doing are meaningful and important. To maximize the interest of the generation for science it is necessary to provide connections with the world that they are living in. Environmental problems are one of the leading topics discussed in our society.

Environmental education is a part of the Framework Educational Programme for Basic Education in the Czech Republic. The Framework Educational Programmes define binding educational norms across various stages: pre-school education, basic education and secondary education. In these framework basic educational areas are presented and also so called cross curricular subjects. One of these subjects is Environmental education. The others are Personal and social education, Democratic citizenship, Education towards thinking in Europian and global contexts, Multicultural education and Media education.
Environmental education promotes individual understanding of the complex and intricate relationship between humans and the environment, i.e. it fosters a realization of the necessity of moving gradually towards sustainable development and acknowledging the importance of taking responsibility for the actions of society and of each individual. The cross-curricular subject helps pupils trace and become aware of humans' dynamically changing relationship to the environment while directly observing current ecological, economic, scientific/technical, political and civic aspects, as well as aspects of time (our relationship to the future) and space (relationships between local, regional and global issues), as well as the possibilities offered by various options for solving environmental issues. It encourages individuals to actively participate in environmental protection, shaping the environment and changing their lifestyle and values in the interest of the sustainable development of human civilisation.

The realization of this cross-curricular subject involves most educational fields. In the educational area of Humans and Nature, it emphasises acknowledging the objective applicability of natural laws and dynamic contexts from less complex ecosystems all the way to the biosphere as a whole, humankind's position in nature and the complex functioning of ecosystems in relation to human society, i.e. for maintaining the conditions necessary for life, for finding renewable sources of raw materials and energy and for non-productive values (inspiration, rest). It proposes a systemic approach which emphasizes the interlinked nature of systems, their hierarchic organization and their relations to the surroundings [3]. 
The cross-curricular subject:

- develops an understanding of interrelationships within the biosphere, humankind's relationship to the environment and the environmental impacts of human activities

- promotes an understanding of the interrelationships between local and global issues and personal responsibility in one's relationship to the environment

- teaches pupils to assess the objectivity and urgency of information on environmental issues

- teaches pupils to talk about environmental issues, to express themselves, and to rationally defend and reason their opinions and standpoints

- promotes personal engagement in issues associated with environmental protection

Thematic areas of the cross-curricular subject are as follow: Ecosystems, Fundamental conditions for life, Human activities and environmental problems, Humankind's relationship to the environment [3].

Environmental education is strongly supported also by NSTA. Over the last decade the UNESCO-UNEP International Environmental Education Programme (IEEP) has developed the Environmental Education Series focussing on the incorporation of EE into primary and secondary curricula, teacher education, general education, technical and vocational education and non-formal education. The EE Series includes prototype modules on environmental themes, on guidelines for EE development, and on EE curricula dimensions for various levels of education [18].

The idea all over the world is the same - environmental education should be a part of the school curriculum because student knowledge of environmental concepts establishes a foundation for their future understandings and actions as citizens.

The impact of environmental education can be summarized as follow:

- Ability of critical thinking

- Observation, experimentation, innovation skills

- Active learning

- Knowledge of environmental issues

- Knowledge about global problems

- Interdisciplinary education

- Problem solving.

\section{Gulf Stream}

Transport processes in the atmosphere are certainly an interesting topic for students. However, at the level of primary and secondary schools these problems cannot be solved comprehensively, because students do not have the necessary mathematical apparatus (differential and integral calculus). These processes can be explained and simulated quite vividly by using very simple experiments. As an example, the model of the Gulf Stream will be presented.

The Gulf Stream is one of the most famous sea currents and, in connection with the problems of global warming, also much discussed. The stream has a profound effect on the climate in Europe. Before the realization of the experiment, it is necessary for the students to get familiar with the basic aspects of a formation of a local produce and an extensive convective flow and the mechanism of it. The formation of the flow is caused by the temperature and density difference between the cold and warm water in the ocean [6].

The Gulf Stream transports up to $1,5.10^{8} \mathrm{~m}^{3}$ water per second. The name was given to it by Benjamin Franklin and comes from the Gulf. Formerly it was called the Florida Current and the Canal de Bahama. To the north of the British Isles it continues as the North Atlantic current. In the Gulf of Mexico the water masses are getting warm, the trade winds pushing this mass of water against America's shores and the stream turns along the North American coast to the north. The Gulf Stream is a merger of the Florida Current and the Antilles Current from the northern part of Bahamas. The current is $100-200 \mathrm{~km}$ wide and about 2,500 kilometers long. The average depth is 1.6 $\mathrm{km}$. Near Cape Hatteras (North Carolina), the current breaks away from the coast and heads into free Atlantic (due to geographic conditions of the seabed). Its flow towards Europe is affected by the collision with the Labrador Current and the influence of the Coriolis force. Due to the division of power, heat radiation and evaporation the current loses some of its energy. With its current speed (about $9 \mathrm{~km} / \mathrm{h}$ ) and cardinality $150 \mathrm{~Sv}$ (1 Sverdrup $=10^{6} \mathrm{~m}^{3} / \mathrm{s}$ ) the Gulf Stream is one of the strongest ocean currents of the world.

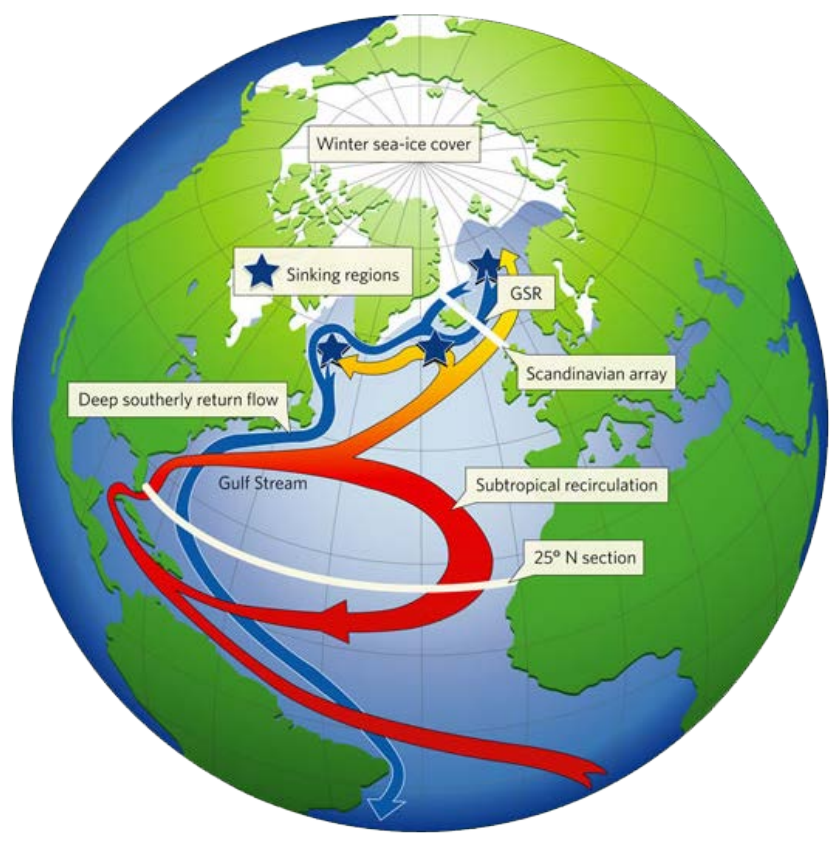

Figure 1. Gulf stream

(http://www.dailygalaxy.com/photos/uncategorized/2007/06/18/gulf_stre am_1.png)

For our purposes we should know the temperature difference between the temperature of the Gulf Stream and the temperature of the surrounding sea. At Cape Hatteras the temperature difference is about $3^{\circ} \mathrm{C}$, in the area between the United Kingdom and Iceland this difference is $7-9^{\circ} \mathrm{C}$, in the North Sea it is $5-8^{\circ} \mathrm{C}$. Salinity of the sea towards the north decreases. From the above data we can calculate $0.8 \mathrm{~kW}$ of energy that can be obtained from a 1 $\mathrm{m}^{3}$ of flowing water.

\section{Model of the Gulf Stream}

Glass aquarium is filled with salt water of a room temperature. Over one end of the aquarium a $500 \mathrm{~W}$ 
halogen lamp is placed (simulates the Sun). The lamp is switched on and the water is heated for about 20 minutes under this hot source (a classic light bulb works too, the heating time must be increased up to 30 minutes). After 20 minutes some ice (in a net) is placed into the water on the other end of the aquarium. On the net container another wire should be placed to be able to regulate the degree of ice immersion. The ice should be only a few centimeters immersed for the surface layers of water could easily flow under it. There must be a sufficient amount of ice. A little amount of ink (blue or red) is dropped into the water under the source of heat. The flow direction from the heat source to the ice can be observed. When the water reaches the ice region it fits neatly beneath the ice, cools and sinks to the bottom of the aquarium. Bottom water flows back to the heat source.

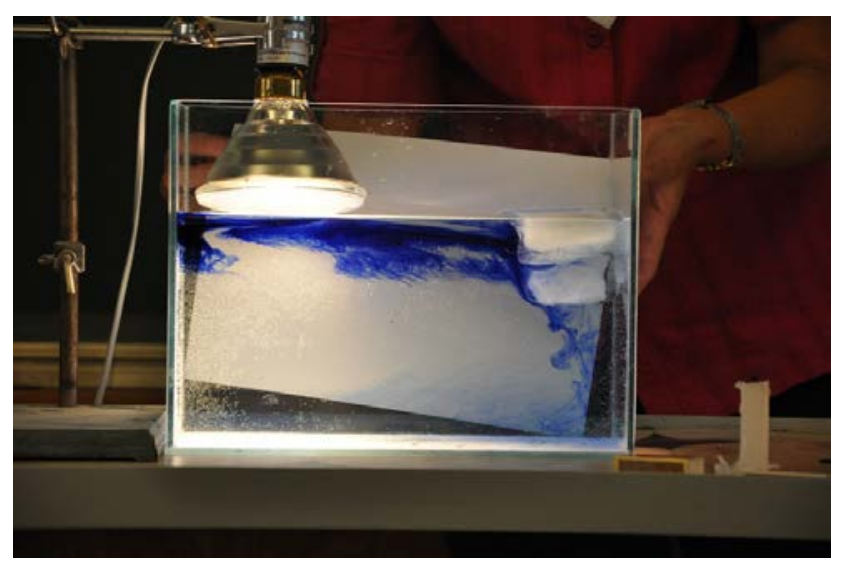

Figure 2. Gulf Stream experiment

\subsection{Quantification of the experiment:}

The dimensions of the aquarium we have used were: $46.5 \mathrm{~cm} \times 24.5 \mathrm{~cm} \times 30 \mathrm{~cm}$. This container was filled with water up to a height of $14 \mathrm{~cm}$ and about $100 \mathrm{~g}$ of salt was poured onto it. Water and salt was thoroughly mixed and left for about 2 hours. In the freezer two ice cubes have been prepared - plastic cups (500 g) were filled in water and left to freeze. These ice cubes can be easily removed from the cups and are quite sufficient for the given amount of water in the aquarium.

The water temperature in the aquarium was stabilized at $27.5^{\circ} \mathrm{C}$ (the room temperature was $27^{\circ} \mathrm{C}$ ). Then a rack on the left end of the aquarium built stand was placed to which a $120 \mathrm{~W}$ bulb was attached. The bulb was set to "hang" about $1 \mathrm{~cm}$ above the water surface.

The lamp was switched on and started to heat the water below the bulb. The bulb simulates the sun that warms sea water mass around the equator. The water temperature was repeatedly measured $1 \mathrm{~cm}$ below the surface directly under the bulb. The water temperature increased only slowly. After 5 minutes of switching on the bulb the temperature of the water has raised to a value of $30.1^{\circ} \mathrm{C}$. After 10 minutes, the temperature was $33.5^{\circ} \mathrm{C}$, after 15 minutes $-40^{\circ} \mathrm{C}$ and after 20 minutes $-44^{\circ} \mathrm{C}$. The temperature at the opposite end of the aquarium was stabilized at $28.2^{\circ} \mathrm{C}$ in 15 minutes after switching on the lamp. At the moment when the water temperature under the lamp reached $44^{\circ} \mathrm{C}$, the ice from the freezer was took out and carefully immersed into the water at the opposite end of the aquarium. After about two minutes some ink was dropped into the water under the lamp. The colored ink makes visible the flow of warm water towards the area with ice cubes, it is easy to see how the flowing water fits neatly beneath the ice, sinks to the bottom and heading back to the "warmer" areas under the lamp. Shortened record of our experiment can be watched on youtube: https://www.youtube.com/watch?v=V-AisxzZMjM.

The same mechanism can be observed in the real flow of the Gulf Stream - after the cooling that causes the increase of water density the water sinks to the bottom and then returns toward the south.

After inserting ice into the water, the temperature in different parts of the aquarium (using the contact thermometer Vernier) was measured. Temperatures were measured successively under the lamp at a depth of $1 \mathrm{~cm}$ below the surface, then under the lamp $1 \mathrm{~cm}$ above the bottom. The second measurement was taken in the middle of the aquarium; $1 \mathrm{~cm}$ below the surface and at the bottom, the last measurement was taken in the ice area, $1 \mathrm{~cm}$ below the surface and above the bottom. The temperature gradients were calculated, which were $18^{\circ} \mathrm{C}$ between the temperature under the lamp and in the middle of the aquarium, and $6^{\circ} \mathrm{C}$ between the middle of the aquarium and ice area. Between the temperature of water under the lamp and the temperature of water in the ice area, the temperature difference was $24^{\circ} \mathrm{C}$.

Let us compare these values with the Gulf Stream ones. For this purpose the published data on sea and currents temperatures were used (http://www.esrl.noaa.gov/psd/ map/clim/sst.shtml).

The average value of the sea temperature in the Florida Straits is $26.7^{\circ} \mathrm{C}$; sea temperature in the tropics in summer is $28^{\circ} \mathrm{C}$, the average value is reported to be about $26{ }^{\circ} \mathrm{C}$. The sea temperature in the northern areas, where the Gulf Stream sinks is $-1^{\circ} \mathrm{C}$. These temperature differences are analogous to the temperatures measured in our model.

From the measured values it can be seen that with this simple model, there were significant differences in the temperature region below the lamp and on ice. The temperature difference is sufficient to enable the flow of water being established similar to that in the Gulf Stream. The chart also allows calculating the temperature differences in certain point just below the surface and at the bottom. Color ink insertion makes the water flow in the aquarium sufficiently visible. For realization of the experiment I would propose the use of several thermometers to be securely mounted at a given location. Transporting a thermometer is often problematic, it is important to maintain the aquarium water without disturbing.

This experiment provides only a simple flow model. The Gulf Stream is a complex and complicated mechanism which is an internal part of the world's oceans. On the model we can show that the cooled layer of water is unable to rise back to the surface.

\section{Discussion}

\section{a) Impact of the Gulf Stream.}

Ocean currents circulate water of different temperatures all over the globe, so they have a significant impact on the world's climate and weather patterns. The greatest impact the Gulf Stream has on climate can be seen in Europe. For 
example Ireland and England are much warmer than they would otherwise be their latitude. So the average low temperature in London in December is $5^{\circ} \mathrm{C}$ while in St. John's, Newfoundland, at the same latitude, the average is $-3^{\circ} \mathrm{C}$. The Gulf Stream and its warm winds are also responsible for keeping northern Norway's coast free of ice and snow.

\section{b) And what about the catastrophic scenario - global warming and the Gulf Stream?}

You can read a lot of assays that the Gulf Stream is slowing down. Flow stops when all the ice has melted. A layer of melted ice is formed on the salt water due to melting of ice in the northern Polar Regions, Greenland. This layering is stable, the flow does not occur.

This situation can be easily demonstrated by a simple experiment. A deep glass container is filled with salty water at room temperature. About $30 \mathrm{~g}$ of salt is necessary for a $100 \mathrm{ml}$ glass of water. A day before ice cubes colored with food coloring are prepared in the freezer. These ice cubes are very carefully placed on the water surface. After about 5 Minutes we can observe the process - a colored layer of melted ice is formed on the salt water. This layering is stable, the coloured water does not flow.

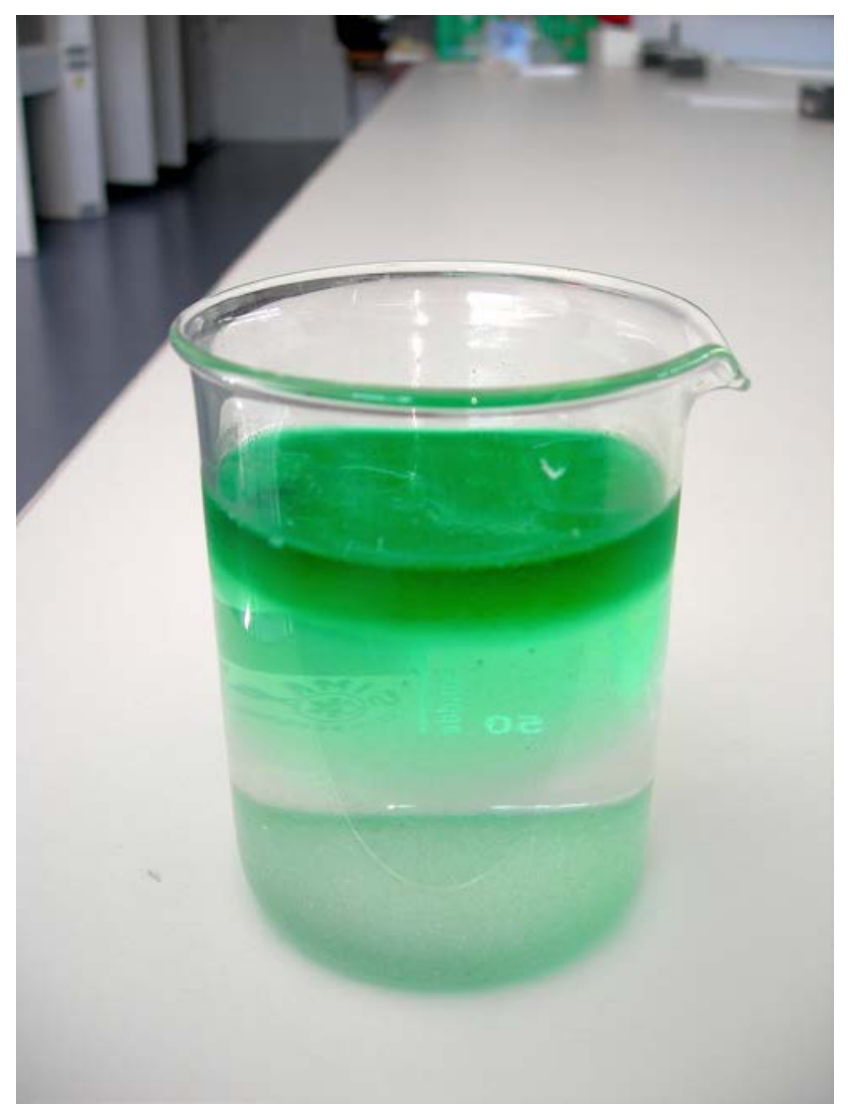

Figure 3. Layers in salty water

In a similar way the temperature in the upper layer and at the bottom is measured (see Figure 4).

A slowing down of the Gulf Stream in the north Atlantic is predicted to lower the temperature over Europe by $4^{\circ} \mathrm{C}$. In history, the Gulf Stream caused temperature changes - 10,000 years earlier - at the height of the last ice age the temperature in Europe had been more than $10^{\circ} \mathrm{C}$ lower then now. And the strength of the Gulf stream was only about two-thirds of the strength it has now. Most of northwestern Europe was a frozen wasteland.
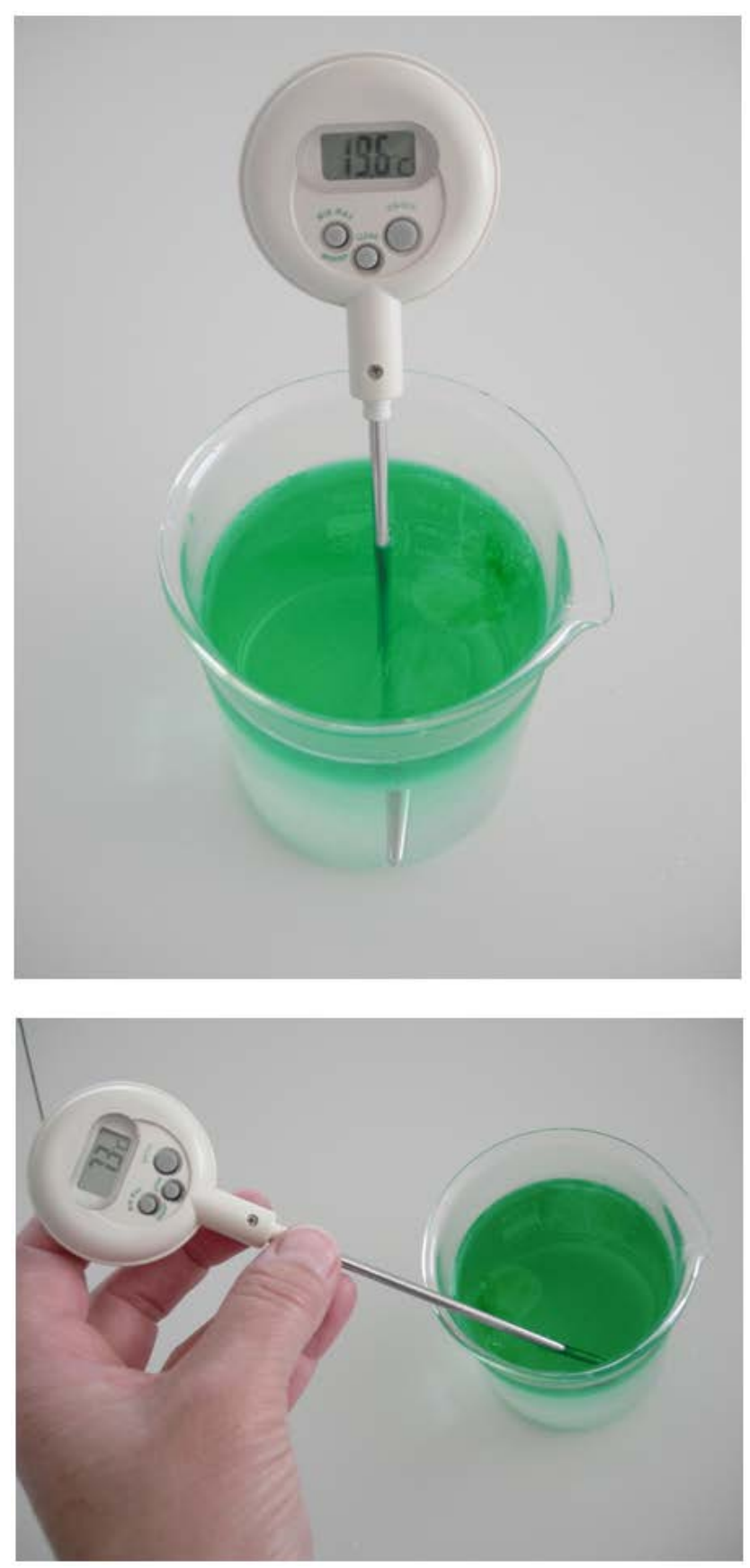

Figure 4. Temperature near the bottom $\left(19.6{ }^{\circ} \mathrm{C}\right)$ and in the layer with melted ice $\left(7.3^{\circ} \mathrm{C}\right)$

\section{c) The Gulf stream and hurricanes.}

The Gulf Stream is still the subject of investigation of various world teams (Hokkaido University, University of Hawaii), who have confirmed the influence on current events in the troposphere and thus the influence on the weather in the northern hemisphere. [13]

A new study reveals that the Gulf Stream anchors a precipitation band with upward motions and cloud formations that can reach 7 miles high and penetrate the upper troposphere

Warmer tropical seas could be the reason for the increase in hurricane activity.

\section{Conclusion}

The described experiment was prepared as a part of the modul Environmental Physics presented at high schools. 
The basic knowledge about heat transfer in the atmosphere and in the ocean can be farther discussed in Physics lessons. This activity promotes the 21st century skills of learners. For example:

- Critical thinking, problem solving, reasoning, analysis, interpretation, conceptual synthesis

- Research skills and practices, interrogative questioning

- Creativity, artistry, curiosity, imagination, innovation, personal expression

- Perseverance, self-direction, planning, self-discipline, adaptability, initiative

- Oral and written communication, public speaking and presenting, listening

- Leadership, teamwork, collaboration, cooperation, using virtual workspaces

- Information and communication technology (ITC) literacy, media and internet literacy, visual interpretation, data interpretation and analysis, computer programming

- Civic, ethical, and social-justice literacy

- Economic literacy, financial literacy, entrepreneurialism

- Global and multicultural literacy, humanitarianism

- Scientific literacy, technical reasoning, using the scientific method

- Environmental and conservation literacy, ecosystems understanding

- Health and wellness literacy, including nutrition, diet, exercise, and public health and safety.

Millennials get information and knowledge easy from the Internet, newspapers, magazines. They can find information about every topic they are interested in. The information and knowledge are increasing day by day and it is very difficult to find relevant and scientific correct materials. Students need to be informed and taught how to find, analyze and exploit the information. Millennials need to gain skills they make it possible to be used in real life situations. Science subjects with the research, analytical, problem solving methods are most suitable for this approach. In environmental education students have to be informed about global problems, issues about the sustainable development. Environmental education is a complex topic, global issues are interrelated, basic knowledge in physics, chemistry, geography, biology so as social sciences is necessary. The system of knowledge is a never ending story, and is developing in the time. Environmental and global education is a lifelong task. Only step by step learners get information that they need for everyday life.

\section{Acknowledgement}

This manuscript is supported by the project Modules as an innovational tool in the framework of integration teaching of modern physics and chemistry, $\mathrm{N}^{0}$. CZ.1.07/2.2.00/28.0182 and the project MaT'SMc PROJECT Co-funded by the Lifelong Learning Programme of the European Union.

\section{References}

[1] Archer, D., Rahmstorf, S. The climate crisis, Cambridge University Press, 2010.

[2] Brophy, J., Motivating students to learn, Lawrence Erlbaum Associates, Publishers Mahwah, New Jersey London, 2004.

[3] Framework Educational Programme for Basic Education, VUP Prague 2007.

[4] Franz, J. (2010). Improving K-12 science education. American Physical Society, 19(7). [Online]. Available: http://www.aps.org/publications/apsnews/201007/backpage.cfm. [Accessed Jun.30, 2015].

[5] Flannery, T., We are the weather makers, Text Publishing, 2010.

[6] Gyory, J., Mariano, A.J., Ryan, E.H., "The Gulf Stream." Ocean Surface Currents.”. [Online]. Available:

http://oceancurrents.rsmas.miami.edu/atlantic/gulf-stream.html. [Accessed Jun.30, 2015].

[7] Holubova, R. (2005). Environmental physics: Motivation in physics teaching and learning. Journal of Physics Teacher Education On-line, 3(1), 17-20.

[8] Holubova, R., "Improving the quality of teaching by modern teaching methods”, Problems of education in the $21^{\text {st }}$ century , 25, 58-65, 2010.

[9] Hunt, J., Tucciarone, J., “The Challenges and Opportunities of Teaching „Generation Y”, Journal of Graduate Medical education, 458-464, December 2011.

[10] Mac Leod, K., "Physics Education and STSE: Perspectives From the Literature”, European J of Physics Education , 4(4), 2013.

[11] Mamlok, R., "How can we motivate high school students to study science?”, Science Education International, 22(1), 5-17, 2011.

[12] Metz, S., "Motivating the Millennials", The Science Teacher, 78(6), 2011.

[13] Minobe, S., Kuwano-Yushida, A., Komori, N., Xie, S.-P., Small, R.J., "Influence of the Gulf Stream on the troposphere", Nature, March 13, 2008.

[14] Ocean service education - currents, [Online]. Available: http://oceanservice.noaa.gov/education/kits/currents/06conveyor.h tml, [Accessed Jun.30, 2015].

[15] Osborne, J., Dillon, J., Science education in Europe: Critical reflections, London: The Nuffield Foundation, 2008.

[16] Palmer, D., "What is the best way to motivate students in science?”, Teaching Science: The Journal of the Australian Science Teachers, 53(1), 38-45, 2007.

[17] Taylor, F.W., Elementary climate physics, Oxford University Press, 2005.

[18] UNECO-UNEP International Environmental Education Programme, Environmental Education Series 9, Division of Science, Technical and Environmental Education [Online]. Available:

http://www.unesco.org/education/pdf/333_14.pdf. [Accessed Jun.30, 2015]. 